\title{
Rapid response to supporting learning and teaching: A whole of university approach
}

\author{
Chris Campbell \\ Griffith University \\ Australia
}

\author{
Simone Poulsen \\ Griffith University \\ Australia
}

\begin{abstract}
One university responded rapidly to the changing landscape of higher education to support staff during this time. There are seven support mechanisms that have been put into place across the university to assist staff. Results show data that reports on these mechanisms and that they are seemingly successful, except for the Support Line which has since been reconfigured to still provide support for the small number accessing it. The results also show that a rapid response, if targeted, is able to provide just in time support and training to staff when moving rapidly online. Through the use of the online engagement framework it can be seen that by supporting staff through the seven mechanisms, staff are in a better place to ensure that students are engaged while learning online.
\end{abstract}

Keywords: higher education, COVID-19, pandemic, academic support, university-wide support, VLE

\section{Introduction}

COVID-19 has impacted us in many ways, particularly in the way we work. Most universities have moved towards increasing online provisions and while Griffith University already had the Digital Campus as the university's third largest campus (Griffith University, 2020b), this was still a stretch with students stuck in China and firewalls present. As the pandemic was declared and progressed, teaching moved to online. This paper details and evaluates the seven support mechanisms put into place across the university very quickly and as a direct response to the pandemic. The support mechanisms were put into place to assist approximately 4000 academic and professional staff (Griffith University, 2020a) as they transitioned rapidly to online teaching.

While teaching programs have been moved online at a rapid pace (Parkin \& Brown, 2020) due to the pandemic, there is a need to support this rapid change and in response Griffith University has developed the seven support mechanisims to assist staff in a variety of ways. While Parkin and Brown suggest five faces of transformational leadership, the support mechanisms meet several of these including the crisis, compassional, collaborative and creative leadership and this has in part allowed staff to be well supported with the changing nature of their learning and teaching activities.

The seven support mechanisms for staff put into place in late March include the COVID-19 L\&T:

- Support Line, a phone line for pedagogical support.

- Engagement Community, a Microsoft Teams space for questions about educational technology and teaching practice, where staff can seek help and help others.

- Support Resources, an internal SharePoint site for staff with learning and teaching resources.

- Development Support, webinars provided each week on a variety of learning and teaching topics including assessment, and educational technology tools.

- Ultra Lounge, a twice weekly drop-in session conducted in Collaborate Ultra.

- FAQs provides answers to common learning and teaching related questions.

- Weekly Support Newsletter emailed to staff with content provided in a systematic timely way.

These are outlined in detail in Table 1 and provide an overview of how the seven support mechanisms were put into place. While each one of the mechanisms is independent of the others, the fact there are so many gives well rounded support in learning and teaching in this difficult time. 
Table 1: Outline of the seven support mechanisms put into place at the university.

\begin{tabular}{|c|c|c|c|c|c|c|c|}
\hline & $\begin{array}{l}\text { COVID-19: } \\
\text { L\&T Support } \\
\text { Line }\end{array}$ & $\begin{array}{l}\text { COVIDE-19: } \\
\text { L\&T } \\
\text { Engagement } \\
\text { Community }\end{array}$ & $\begin{array}{l}\text { COVID-19: } \\
\text { L\&T Support } \\
\text { Resources }\end{array}$ & $\begin{array}{l}\text { COVID-19: } \\
\text { L\&T Prof } \\
\text { Development } \\
\text { Support }\end{array}$ & $\begin{array}{l}\text { COVID-19: } \\
\text { L\&T Ultra } \\
\text { Lounge }\end{array}$ & $\begin{array}{l}\text { COVID-19: } \\
\text { L\&T FAQs }\end{array}$ & $\begin{array}{l}\text { COVID-19: } \\
\text { L\&T Support } \\
\text { Newsletter }\end{array}$ \\
\hline What is it? & $\begin{array}{l}\text { Virtual support } \\
\text { one on one on } \\
\text { specific L\&T } \\
\text { challenges and } \\
\text { how to address } \\
\text { these } \\
\text { pedagogically }\end{array}$ & $\begin{array}{l}\text { Collaboration } \\
\text { Discussions } \\
\text { Questions } \\
\text { Sharing ideas, } \\
\text { challenges } \\
\text { Link to } \\
\text { resources, not } \\
\text { a document } \\
\text { repository }\end{array}$ & $\begin{array}{l}\text { L\&T Support } \\
\text { resources and } \\
\text { document } \\
\text { management } \\
\text { hub } \\
\text { One top shop } \\
\text { for L\&T } \\
\text { resources }\end{array}$ & $\begin{array}{l}\text { Virtual support } \\
\text { to large groups } \\
\text { on L\&T } \\
\text { pedagogy } \\
\text { practice and } \\
\text { application of } \\
\text { technologies to } \\
\text { support this }\end{array}$ & $\begin{array}{l}\text { Regular, end } \\
\text { user-led virtual } \\
\text { support to } \\
\text { small groups } \\
\text { on L\&T } \\
\text { pedagogical } \\
\text { queries }\end{array}$ & $\begin{array}{l}\text { Common L\&T } \\
\text { related } \\
\text { questions and } \\
\text { answers } \\
\text { Support for } \\
\text { L\&T } \\
\text { community to } \\
\text { answer } \\
\text { questions in a } \\
\text { common and } \\
\text { consistent way }\end{array}$ & $\begin{array}{l}\text { News } \\
\text { Internal } \\
\text { updates and } \\
\text { messages } \\
\text { Upcoming } \\
\text { support } \\
\text { activities }\end{array}$ \\
\hline $\begin{array}{l}\text { How does it } \\
\text { provide } \\
\text { support? }\end{array}$ & $\begin{array}{l}\text { Help from } \\
\text { subject matter } \\
\text { experts }\end{array}$ & $\begin{array}{l}\text { Help from } \\
\text { subject matter } \\
\text { experts and } \\
\text { each other }\end{array}$ & Self-help & $\begin{array}{l}\text { Planned help } \\
\text { from subject } \\
\text { matter experts }\end{array}$ & $\begin{array}{l}\text { Planned help } \\
\text { from subject } \\
\text { matter experts }\end{array}$ & $\begin{array}{l}\text { Answers about } \\
\text { current L\&T } \\
\text { environment }\end{array}$ & $\begin{array}{l}\text { Information } \\
\text { about planned } \\
\text { support }\end{array}$ \\
\hline Method & $\begin{array}{l}55555 \\
\text { Telephone } \\
\text { service } \\
\text { support form }\end{array}$ & $\begin{array}{l}\text { Microsoft } \\
\text { Teams site }\end{array}$ & $\begin{array}{l}\text { Microsoft } \\
\text { SharePoint site }\end{array}$ & $\begin{array}{l}\text { Virtual } \\
\text { workshops }\end{array}$ & $\begin{array}{l}\text { Virtual support } \\
\text { via } \\
\text { Collaborate } \\
\text { Ultra }\end{array}$ & $\begin{array}{l}\text { Operational } \\
\text { L\&T FAQS- } \\
\text { L\&T Support } \\
\text { Resources } \\
\text { Strategic L\&T } \\
\text { FAQs } \\
\text { COVID-19 } \\
\text { site }\end{array}$ & $\begin{array}{l}\text { CVent } \\
\text { distribution }\end{array}$ \\
\hline
\end{tabular}

These seven support mechanisms for staff are aimed at assisting academics following a just in time principle as well as a more systematic approach to enhance all learning and teaching staff's professional development. The phone call to the new pedagogical Support Line and the Ultra Lounge, a drop in session as well as the L\&T Support Resources, the Teams L\&T Engagment Community and the L\&T FAQs all provide just in time support to staff. The Professional Development Support, through the regular online workshops/webinars and the L\&T Support Newsletter provide staff with more of a professional development approach with staff attending webinars and reading sections of the weekly newsletter as relevant to them at the time. All the webinars are recorded so staff unable to attend are able to watch them at a later date. The PowerPoint slides are available for staff so that they can engage with the slides as well as use any that might be useful in their own teaching, such as the 'record' slide, 'features of Collaborate Ultra' and the 'Acknowledgement of Country' slide.

\section{Literature Review}

Online education is increasingly seen as a scalable means to provide courses to an increasingly nontradational student population (Brown. et al., 2020). But for this to happen, academics need to be prepared. Blended and fully online learning require a range of design skills that academics often do not have (Glasby, 2015). Without the access to suitable technology support, most are likely to fall back onto tried classroom teaching. While various universities are addressing the need for professional development to accommodate the rapid shift online, it is still too early to report the studies. However one study reports on how they are improving the Teacher Educator Technology Competencies (TETCs) (Foulger et al., 2017) through a professional development program for teacher educators at their university (Foulger et al., 2020). Another study reported distance professional learning for the school system with online learning and peer mentoring being conducted in the school system for staff with anecdotal evidence this is working well (Gonzalez-Dogan \& Dogan, 2020). Technology by itself does not yield the greatest impact on learning, it does so when embedded in a scaffolding of support for learners and instructors (Glasby, 2015).

While there is limited literature on higher education students studying online during a pandemic, one study, reported via Educuase (Veletsianos \& Kimmons, 2020), reported analysing a week of tweets to learn what students were wanting. They report that students appreciate faculty who are calm and positive in their nature, who maintain perspective and who are empathetic, flexible with reasonable expectations. They also report that students want staff who are comfortable with using educational technology (Veletsianos \& Kimmons, 2020). 
Students are also looking for more connected and mobile learning opportunities (Glasby, 2015) that can take learning beyond the traditional delivery of information. The support mechanisms are in place to assist staff with these things and ensure they are well informed. While one study suggested that students prefered to complete class activities face-to-face rather than online as they felt that in face-to-face classes they felt more engaged and also received feedback immediately. However, the study also reports that there was no significant difference in test performance (Kemp \& Grieve, 2014). This might be improved with newer technologies now available and the creation of high quality virtual content such as experiential and online labs and pedagogy changes such as learning in shorter sprints than the standard 50 minute lecturer (Puri, 2020).

One previous body suggests an online engagement framework for higher education (Redmond et al., 2018). The online engagement framework developed from a strong literature review includes several elements which are social engagement, cognitive engagement, emotional engagement, collaborative engagement and behavioural engagement that "is a multidimensional construct with interrelated elements that impact on student engagement in online settings" (Redmond et al., 2018, p. 190). When looking at the student engagement literature, the three areas of behaviourally engaged, emotionally engaged and cognitive engagement (Weimer, 2016, June 22) come up which also supports Redmond et al. (2018). Using this framework, it can be seen that by encouraging the online engagement element in the seven support mechanisms, this will allow for both staff development in skills and online engagement and it will then hopefully in turn transfer over to online student engagement in their classes.

One important aspect when providing support is to ensure that students are engaged but also feel a sense of community in their courses. This is why the online engagement framework (Redmond et al., 2018) so fully allows for Griffith University's learning and teaching themes of active learning, authentic learning and collaborative learning to be upheld. This was done in part by ensuring that any new tools suggested for the new online learning and teaching environment were already connected to the teachers' existing practices as previously identified (Bennett et al., 2017). Griffith University offers a range of tools in their virtual learning environment (VLE) that augment the traditional learning management system (see Figure 1), while also having features that seek to actively engage students in their learning (Poulsen et al., 2019). These tools are also helpful in ensuring students have active, authentic and collaborative learning experiences. When active learning is used, there is greater retention of course material (Miller et al., 2013; Smith \& Cardaciotto, 2011). Previous research also suggests that ensuring success to active learning is for the academics to adopt active learning pedagogies in a small way and then to increase their use (Campbell \& Blair, 2018).

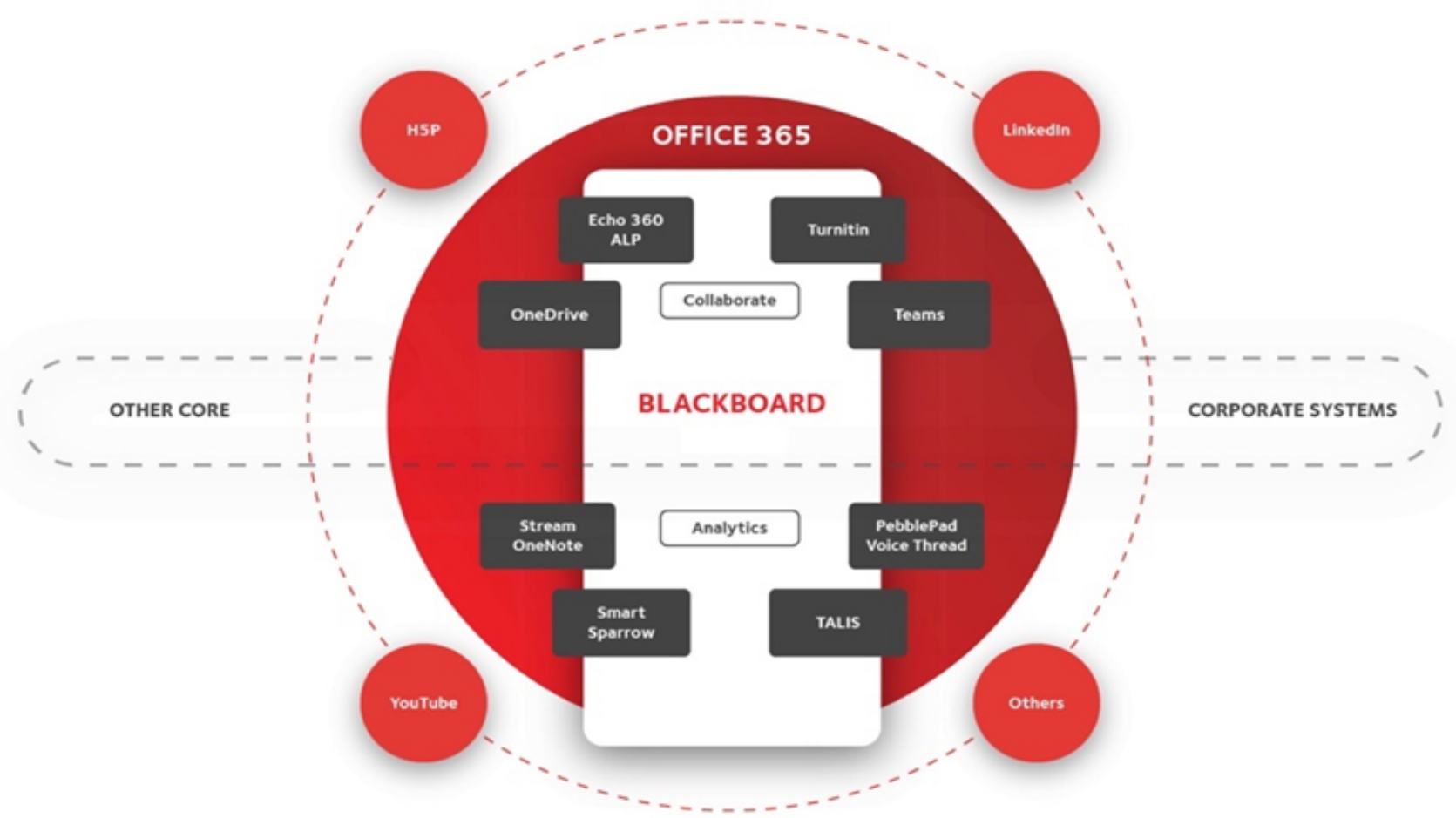

Figure 1. Griffith University virtual learning environment (VLE) (Poulsen, Campbell \& Sankey, 2019).

The literature review lead to the development of the research questions:

1. What is the development and uptake of the seven support mechanisms? 
2. Is there a need for certain types of support in the changing nature of online learning and teaching in the current environment?

\section{Methodology}

Data for this paper were gained from the use of the seven support mechanisms and is reported below. As all data is general in nature and not identifiable in any way, no ethics approval was necessary. Data were provided through the analytics available from the various platforms. For instance, in the Microsoft Teams space, the data were downloaded for the 90 days until the $26^{\text {th }}$ June. This is the maximum data that is kept, and it is very general in nature.

The L\&T Support line had data that were kept through the system and are then reported below. The Ultra Lounge has an event log that is manually updated weekly and data were drawn from this. The Learning and Teaching SharePoint site, being a Microsoft product, also had limited data. However, what was able to be gathered is reported below.

Data for the Learning and Teaching FAQs site was requested from the website managers at Griffith University and the overall stats were given, but not greater detail. The weekly newsletter data is from the emails sent and the system used while the webinars is from the registration system and the record of those who turned up via the Collaborate Ultra reports.

\section{Results}

The results are outlined below and reported through the headings of the seven support mechanisms to provide a clear understanding of when these were implemented and how these are now assisting staff during this time.

\section{L\&T Support Line}

Although there was already a support line to meet staff technical needs, this was extended with pedagogical support for staff. The pedagogical service was offered by the central teaching unit's educational designer and project management staff and was offered for 10 weeks (8 April to 19 June 2020) from 10am to 4pm Monday to Friday. Although advertised through the weekly L\&T newsletter, only 41 support requests were made during this time. From these calls, six were sent back to the IT helpline while 35 were seen as pedagogical requests for support and the academic was assisted. However, it should be noted some of these were quite technical in nature, however the team still assisted. Of the 35 requests, there were 20 made by phone and 12 via an available web form and three were made via email. This represents an average of 3.5 requests for assistance per week. Thus, a small number of staff used the service, however anecdotally those that did found the assistance helpful. The number of staff required to manage the specific hotline meant that it was discontinued in that format from the $20^{\text {th }}$ June. The replacement service is that staff contact the central help desk and the job is then logged which means a team member is able to pick up the job and work on it quickly, but without staff resources being taken up to monitor the phone line. Currently the query is solved within 30 minutes of being logged.

\section{Ultra Lounge}

The Ultra Lounge was designed to assist staff with their transition to teaching online. Although Griffith University has many online courses and the digital campus is the third largest campus, often larger courses are taught both online and face to face. In some of these instances however it might be that only one staff member from the team actually teaches online while the rest of the team teach face to face. Thus, the university-wide transition to online teaching needed strong support while being just in time. The Ultra Lounge was staffed by experienced staff who have a good range of skills in educational technologies such as Collaborate Ultra including break out rooms, Microsoft Teams, and video tools such as Stream, and Echo360 ALP. The Lounge is a safe place for staff to both learn how to use the technologies as well as practice in a safe place. After they attend the Lounge staff are sent a follow up email. They are offered an individual session if needed or support in their first online class. This support is taken up at times.

The Ultra Lounge began in the middle of March however it was then delayed until the $30^{\text {th }}$ March as it had not been advertised. Initially the Lounge was at $2 \mathrm{pm}$ for an hour five days a week, however from the $20^{\text {th }}$ April, the Lounge went to two days per week. The Lounge was initially supported by two staff each day, however due to numbers attending it was dropped to one staff member. By June, once staff were using the Lounge more each session, it was once again attended by two staff members, who generally have complimentary skills to ensure a large range of topics can easily be covered. 
Table 2: Ultra Lounge numbers and individual consultations for each month.

\begin{tabular}{|c|c|c|}
\hline Month & Ultra Lounge Attendees & Individual Consultations \\
\hline March & 5 & 2 \\
\hline April & 24 & 1 \\
\hline May & 3 & 2 \\
\hline June & 11 & 4 \\
\hline July & 15 & $\mathbf{1 7}$ \\
\hline Total & $\mathbf{5 8}$ & \\
\hline
\end{tabular}

As can be seen by Table 2, the Ultra Lounge numbers varied each month with more individual consultations offered in March and more staff attending when the Lounge was open five days per week in April. In June the Ultra Lounge was advertised with a book in system for 15 minute timeslots (although it should be noted that sessions are generally 30-45 minutes in length for each staff member). This booking system also gave notice of the type of assistance being required so relevant Subject Matter Experts could be consulted or brought in to address the query if staff supporting the Lounge were unable to answer the query.

\section{Microsoft Teams}

At the beginning of the pandemic in Queensland (1 $7^{\text {th }}$ March) and as part of the rapid response, a Microsoft Team was created with many staff being manually added to the team. The team, called COVID-19: L\&T Engagement Community, has four channels and a private operational channel. There are now 1311 members plus 11 owners of the team. The owners can add new staff and answer questions that are asked by the members. The tagging system in Teams is currently enabled to assist staff in a faster way. Channels include the General channel, 1. Breaking news and Announcements, 2. Get Help and Help Others, 3. COVID-19 Resources, and 4. Leading the Way.

Engagement varies but in the 90 days from the $28^{\text {th }}$ April to the $26^{\text {th }}$ July, there were 1322 users, 224 posts, 542 replies, 417 mentions, and 458 reactions. There were only 15 inactive users during this time. The most used channel, 2. Get Help and Help Others had 63 posts, with 249 replies, 163 mentions and 154 reactions.

\section{Learning and Teaching SharePoint}

In late March, one of the first support mechanisms created was an internal SharePoint website for all staff about learning and teaching. This site is modified, changed and improved on a weekly basis and includes such topics as educational technology, strategies for teaching online and engaging students, webinar resources, and support contacts. To date there have been 40,834 lifetime site visits. One example of staff accessing the site is on Thursday $16^{\text {th }}$ April when 142 unique users accessed the SharePoint site for 412 site visits meaning they accessed more than one page on the SharePoint site.

\section{Learning \& Teaching FAQs}

A website with Learning and Teaching FAQs was developed and released on the $1^{\text {st }}$ April. This site continues to grow with Q\&As taken from questions asked in webinar registrations and from the webinars themselves as well as from a variety of other source points. To date the website has had over 7204 page views with 5285 unique views. This is a public facing website and as such views may be from those external to Griffith University.

\section{Webinars}

It was identified at the start of the pandemic that webinars would be helpful for staff to gain just in time training to ensure they had the skills required in order to put their teaching online. The first webinar was conducted on the $18^{\text {th }}$ March with four webinars conducted that first day, and a further four run the next day. Initially each session was to be capped to 50 attendees, however when bookings kept coming in, the cap was removed completely. They were each one and a half hours duration with the first one at 8:30am and the fourth one finishing at $5 \mathrm{pm}$.

Initially staff training used a just in time philosophy to ensure that staff had the necessary skills in order to move their teaching online. However, as things unfolded, the long term needs of the staff were considered and the webinars became a tool of systematic professional development across the university. Table 3 shows the webinars and the number of times the session was conducted as well as the number of staff who registered and the number who actually attended. It should be noted that staff often attended who did not register as the link into the training sessions was the same. It was decided the webinars would each go for a maximum of 1.5 hours although many go longer as participants enjoy discussing the topics with the presenters. 
Over time there was development in how far in advance the webinars were developed as well as in sending reminders for the training so that the attendance generally increased in comparison to the registrations. As can be seen, a large amount of training has been conducted by the webinar team.

Table 3: The names of webinars, number of sessions and those who attended.

\begin{tabular}{|c|c|c|c|c|c|c|c|}
\hline Title & $\begin{array}{c}\text { Number } \\
\text { of } \\
\text { sessions }\end{array}$ & $\begin{array}{l}\text { Number } \\
\text { registered }\end{array}$ & $\begin{array}{l}\text { Number } \\
\text { attended }\end{array}$ & Title & $\begin{array}{c}\text { Number } \\
\text { of } \\
\text { sessions }\end{array}$ & $\begin{array}{c}\text { Number } \\
\text { registered }\end{array}$ & $\begin{array}{l}\text { Number } \\
\text { attended }\end{array}$ \\
\hline $\begin{array}{l}\text { Putting Lectures } \\
\text { Online (Using } \\
\text { Echo360 and } \\
\text { Collaborate Ultra) }\end{array}$ & 8 & 428 & 517 & $\begin{array}{l}\text { Getting started with } \\
\text { Teams }\end{array}$ & 3 & 80 & 63 \\
\hline $\begin{array}{l}\text { Using Microsoft } \\
\text { Teams }\end{array}$ & 10 & 548 & 478 & $\begin{array}{l}\text { Getting started with } \\
\text { PebblePad }\end{array}$ & 1 & 30 & 16 \\
\hline $\begin{array}{l}\text { Breakout Groups } \\
\text { with Collaborate } \\
\text { Ultra }\end{array}$ & 6 & 452 & 361 & $\begin{array}{l}\text { Getting started with } \\
\text { Collaborate Ultra }\end{array}$ & 3 & 75 & 68 \\
\hline $\begin{array}{l}\text { Recording videos / } \\
\text { lectures with } \\
\text { Echo360 and } \\
\text { PowerPoint }\end{array}$ & 4 & 312 & 238 & $\begin{array}{l}\text { Explore tools for } \\
\text { creating video }\end{array}$ & 2 & 110 & 79 \\
\hline $\begin{array}{l}\text { Moving group work } \\
\text { assessment online }\end{array}$ & 5 & 165 & 109 & \begin{tabular}{|l} 
Teams: Next Level \\
\end{tabular} & 3 & 138 & 117 \\
\hline $\begin{array}{l}\text { Moving } \\
\text { presentation } \\
\text { assessments online }\end{array}$ & 5 & 189 & 126 & $\begin{array}{l}\text { PebblePad: Next } \\
\text { Level }\end{array}$ & 1 & 25 & 15 \\
\hline $\begin{array}{l}\text { Re-thinking your } \\
\text { invigilated exam } \\
\text { (other assessment } \\
\text { options) }\end{array}$ & 6 & 210 & 169 & Using VoiceThread & 1 & 40 & 29 \\
\hline $\begin{array}{l}\text { Building student } \\
\text { engagement and } \\
\text { community online }\end{array}$ & 5 & 248 & 200 & \begin{tabular}{|l|} 
Collaborate Ultra: \\
Next Level
\end{tabular} & 3 & 129 & 124 \\
\hline $\begin{array}{l}\text { Active, authentic } \\
\text { and collaborative } \\
\text { online learning in } \\
\text { the VLE }\end{array}$ & 2 & 104 & 59 & \begin{tabular}{|l|} 
Using Padlet \\
\end{tabular} & 2 & 79 & 56 \\
\hline Course Analytics & 5 & 145 & 149 & $\begin{array}{l}\text { Creating content } \\
\text { with Sway }\end{array}$ & 1 & 60 & 38 \\
\hline $\begin{array}{l}\text { Designing your } \\
\text { course curriculum: } \\
\text { An introduction }\end{array}$ & 4 & 48 & 54 & \begin{tabular}{|l|} 
Increasing \\
engagement with \\
Echo360 \\
\end{tabular} & 1 & 48 & 37 \\
\hline $\begin{array}{l}\text { Developing your } \\
\text { course profile: } \\
\text { Learning Outcomes }\end{array}$ & 4 & 45 & 42 & $\begin{array}{l}\text { Blackboard tips and } \\
\text { tricks - the hidden } \\
\text { treasures of } \\
\text { Learning@Griffith }\end{array}$ & 3 & 75 & 68 \\
\hline $\begin{array}{l}\text { Developing your } \\
\text { course profile: } \\
\text { Assessment Plan }\end{array}$ & 4 & 57 & 40 & \begin{tabular}{|l|} 
Using Stream to \\
manage your videos
\end{tabular} & 1 & 12 & 13 \\
\hline $\begin{array}{l}\text { Developing your } \\
\text { course profile: T\&L } \\
\text { Plan }\end{array}$ & 4 & 52 & 35 & $\begin{array}{l}\text { Rocking rubric } \\
\text { writing }\end{array}$ & 1 & 53 & 38 \\
\hline $\begin{array}{l}\text { Design and deploy } \\
\text { online exams }\end{array}$ & 2 & 30 & 23 & $\begin{array}{l}\text { Using SafeAssign to } \\
\text { mark and provide } \\
\text { feedback to students }\end{array}$ & 1 & 40 & 36 \\
\hline $\begin{array}{l}\text { Exploring the } \\
\text { course profile } \\
\text { system \& resources }\end{array}$ & 2 & 27 & 26 & \begin{tabular}{|l|} 
Writing test \\
questions to assess \\
higher order thinking \\
\end{tabular} & 1 & 69 & 42 \\
\hline $\begin{array}{l}\text { Prepare your } \\
\text { learning materials } \\
\text { and activities }\end{array}$ & 2 & 121 & 76 & $\begin{array}{l}\text { Using Turnitin to } \\
\text { mark and provide } \\
\text { feedback to students }\end{array}$ & 1 & 56 & 36 \\
\hline $\begin{array}{l}\text { Develop engaging } \\
\text { online lectures }\end{array}$ & 2 & 173 & 143 & $\begin{array}{l}\begin{array}{l}\text { Mark Centre tips and } \\
\text { tricks }\end{array} \\
\end{array}$ & 1 & 25 & 18 \\
\hline $\begin{array}{l}\text { Design engaging } \\
\text { tutorials }\end{array}$ & 2 & 164 & 96 & \begin{tabular}{|l} 
Total for both \\
columns
\end{tabular} & 113 & 4698 & 3863 \\
\hline
\end{tabular}


Webinars were run to support the tools highlighted in the VLE as these were key tools identified by the university in the shift to online. As shown in Table 3, some topics were repeated at various times throughout the trimester depending on needs ascertained from the Academic Calendar, for example examination preparation, Course Profile due dates, and marking deadlines. Topics were also chosen to ease academic support required by the Academic Group Learning and Teaching Consultants who directed staff to and helped market the webinars to their Group.

The number of staff who conducted the training is also worth noting as there were 15 staff members from the central teaching unit involved in the training and who met weekly to design, discuss and reflect on the webinars. There were also two learning and teaching consultants formally involved in some training, with others attending and informally assisting various sessions. There were two academics from the Academic Groups who conducted training, two Learning and Teaching Consultants from the Academic Groups, one person from student administration and one from the library who also conducted training as part of the webinar series.

\section{Newsletter}

A weekly learning and teaching newsletter was designed, created and then begun on the $30^{\text {th }}$ March. This now goes out weekly on a Friday and includes a focus for each week. The webinars are often part of this focus and are also advertised in the Newsletter. The newsletter contains a weekly focus of content with a message from the PVC(L\&T) as well as video links and other weblinks to resources. The newsletter is emailed to approximately 9000 email addresses and it is opened by approximately 3000 staff members each week. The reason the exact figures were initially unknown is due to the changing staff landscape with additions for inclusion for distribution being sent from human resources, however, there has never been a list for removal distributed. This means that the staff email list grows but not all the email addresses are currently active. However, there is data around the number of staff who open and potentially read the email and that number actually changes each week. From further interrogating the data, it can be ascertained that the number of staff who read the newsletter differs each week. There was a high number of newsletter openings for the first newsletter with 3377 on Monday $30^{\text {th }}$ March. Each week that number is different with the lowest week being 2445 newsletter openings. This occurred on Friday $17^{\text {th }}$ July which was during the mid-trimester break with many staff on leave. The mean of the number of emails opened each week is 2839 . The difference in opening is possibly due to the content that is included in the newsletter, and also initially as a new service staff were interested in what was in the newsletter.

\section{Discussion}

At the beginning of the pandemic, with the quick shift to moving learning and teaching activities online, the university recognised the need to support academics to guarantee they had the skills they needed to allow for effective learning environments for their students. As such, the seven support mechanisms were developed to provide just in time training and support. The development of the support mechanisms outlined in the results suggest they were generally well developed for the target audience.

From the results, it can be seen that there was strong engagement with many of the support mechanisms. Glasby (2015) highlighted that without suitable support in technology, academics are likely to fall back onto their tried and true methods of teaching, which in the current environment, this was not an option. It can be seen that the seven mechanisms of support offered a range of options in respect to both technological and pedagogical support, providing an opportunity for academics to pick up the skills and support they needed. Technology offerings need to support the needs of the academics in delivering their content online (Glasby, 2015) and this is evidenced by the various mechanisms of support provided to navigate the shift to online. The strong technological focus of the webinars provides the support that Glasby (2015) refers to, and as the topics were each week driven by requests for assistance from the Academic Groups, and webinar attendees themselves, they were designed to support the attendees needs creating that just in time support for online delivery.

Anticipating the future is risky (Brown et al., 2020), especially when predicting what support mechanisms will be required in an uncertain learning and teaching landscape. With the sudden and rapid shift to online, one can see the need for support was quickly taken up by the various support mechanisms put in place. How do we gauge what if any may have a place in the future support environment? Aside from the L\&T Support Line, which had a low uptake, staff are continuing to engage consistently with the other support mechanisms. If consistent engagement continues with the support mechanisms, this could be a telling feature of the need to maintain those support mechanisms. We will continue to monitor the statistics on engagement and that should give us an indicator of which support mechanisms if any are needed in the future.

Through using Redmond and colleagues (2018) online engagement framework, it can be seen that the seven mechanisms support it quite well. It thus provides good impact for the support mechanisms. One can see that the 'social engagement' of building a community, creating a sense of belonging and establishing trust (Redmond et 
al., 2018) are strongly provided in the support mechanisms, particularly via the SharePoint site, the professional development webinars and the Ultra Lounge.

With the 'cognitive engagement' section of the framework, staff are encouraged to think critically, and integrate ideas as well as distribute expertise. Once again this is conducted through the professional development webinars as well as the weekly newsletter and staff are then able to integrate new knowledge into their teaching and influence students with their online engagement. With regards to 'behavioural engagement', staff are continuing to develop their academic skills through all seven of the support mechanisms as well as through their developing agency, identifying opportunities and challenges and developing their multidisciplinary skills. 'Collaborative engagement' includes learning with peers, which again is part of the webinars but is also seen in both the Microsoft Teams channel where getting help and helping others is a strong focus. The Ultra Lounge has also provided a focus of collaborate engagement as staff visit the Lounge with colleagues who assist, but as several staff may turn up at the one time, it often becomes very collaborative in nature with staff learning from each other. Professional networks are now developing throughout the university as a result of some of these support mechanisms. With regards to 'emotional engagement' from the framework, the webinars and the Teams site have been helpful for assisting staff to manage expectations on a range of topics both work related and work/life balance related. Thus in turn, staff are able to assist students with their emotional engagement.

\section{Lessons Learnt}

Lessons we learnt along the way included recognising that no one support mechanism fits all staff members. The different options provided complimented each other giving a broad touch point for support to allow academics to obtain the type of assistance required. The topics offered in the webinars were scheduled around events on the Academic Calendar, pain points passed on from the Academic Groups, and feedback received from participants. Timing and topics were key in planning and support provision. This feedback then flowed through to support staff on the various channels so they were aware and could prepare for any requests for assistance and make sure relevent documents and resources were available. In the future, planning for webinars will be conducted longer term and will be planned well in advance.

\section{Limitations}

This project had some limitations with regards to the data collected and used to evidence the seven support mechanisms. Data were at times difficult to locate and various staff across the university were asked to assist. Thus, at times, we were reliant on this data and unable to get more detail. Other systems such as Microsoft have very limited analytics associated with the products. Greater detail in the data may be able to be interrogated more and stronger conclusions drawn. Looking at the processes for gaining data may be something that could be done in the future in order for the study to be stronger. As it stands, the university appears happy with the seven support mechanisms in place.

\section{Conclusion}

This paper outlines the seven support mechanisms put into place to support staff during the pandemic. Most of the support mechanisms were well received with large numbers of staff engaging in the supports. Only one support was not utilised well and due to this, the way the support was given has been changed so that it is less time intensive for staff working on the support. The Microsoft Teams space is still well used and assists staff in a variety of ways where they can seek help as well as help others. The SharePoint site with the support resources is well used and staff are continually accessing the webinar recordings which is a fantastic ongoing support. The webinars themselves were well attended and assisted staff with their rapid shift to online teaching. Although the Ultra Lounge only provides support to a small number of staff, they are given quality support that is quite time intensive and anecdotal feedback is excellent. The learning and teaching FAQs website is still well used and the weekly support newsletter is an excellent source of information for all staff and is accessed widely. Overall, the support mechanisms have assisted staff well with the pivot to online teaching in a period of rapid change.

\section{Acknowledgements}

The research team would like to acknowledge the contributions of Lori Burdon, Sheila McCarthy, Marie Szymanski, Rae Jobst, Jude Williams, Ainslie Searles, and Brad Harrison who assisted in gaining the data. We appreciate their support in this process. 


\section{References}

Bennett, S., Agostinho, S., \& Lockyer, L. (2017). The process of designing for learning: Understanding university teachers' design work. Educational Technology Research and Development, 65(1), 125-145. https://doi.org/doi: 10.1007/s11423-016-9469-y

Brown., M., McCormack., M., Reeves., J., Brooks., D. C., \& Grajek., S. (2020). EDUCAUSE Horizon Report: Teaching and Learning Edition. https://library.educause.edu//media/files/library/2020/3/2020 horizon report pdf.pdf?la=en\&hash=08A92C17998E8113BCB15DCA7B A1F467F303BA80

Campbell, C., \& Blair, H. (2018). Learning the active way: Creating interactive lectures to promote student learning. In S. Keengwe (Ed.), Handbook of Research on Pedagogical Models for Next-Generation Teaching and Learners. (pp. 21-37). IGI Global. https://doi.org/10.4018/978-1-5225-3873-8

Foulger, T. S., Graziano, K. J., Schmidt-Crawford, D., \& Slykhuis, D. A. (2017). Teacher educator technology competencies. Journal of Technology and Teacher Education, 25(4), 413-448. https://www.learntechlib.org/primary/p/181966/

Foulger, T. S., Graziano, K. J., Schmidt-Crawford, D., \& Slykhuis, D. A. (2020). Throw me a lifeline: A professional development program for teacher educators managing the demands from the rapid transition to online teaching. In R. E. Ferdig, E. Baumgartner, R. Hartshorne, R. Kaplan-Rakowski, \& C. Mouza (Eds.), Teaching, Technology, and Teacher Education during the COVID-19 Pandemic: Stories from the Field. (pp. 517-520). Association for the Advancement of Computing in Education (AACE). . https://www.learntechlib.org/p/216903/.

Glasby, P. (2015). Future trends in teaching and learning in higher education. https://itali.uq.edu.au/files/1267/Discussion-paper-Future trends in teaching_and learning.pdf

Gonzalez-Dogan, S., \& Dogan, B. (2020). Together in education, apart from brick and mortar: Rapid professional development for online distance learning. In R. E. Ferdig, E. Baumgartner, R. Hartshorne, R. Kaplan-Rakowski, \& C. Mouza (Eds.), Teaching, Technology, and Teacher Education during the COVID-19 Pandemic: Stories from the Field. (pp. 211-215). Association for the Advancement of Computing in Education (AACE). . https://www.learntechlib.org/p/216903/.

Griffith University. (2020a). About Griffith. https://www.griffith.edu.au/about-griffith

Griffith University. (2020b). Digital campus. Retrieved 5th July 2020 from https://www.griffith.edu.au/aboutgriffith/campuses-facilities/digital?city $=$ online

Kemp, N., \& Grieve, R. (2014). Face-to-face or face-to-screen? Undergraduates' opinions and test performance in classroom vs. online learning. Frontiers in Psychology, 5, 1278-1289. https://doi.org/doi: 10.3389/fpsyg.2014.01278

Miller, C. J., McNear, J., \& Metz, M. J. (2013). A comparison of traditional and engaging lecture methods in a large, professional-level course. Advances in Physiology Education, 37, 347-355. https://doi.org/doi:10.1152/advan.00050.2013

Parkin, D., \& Brown, G. (2020). Creating socially distanced campuses and education project: Final capstone report. https://s3.eu-west-2.amazonaws.com/assets.creode.advancehe-documentmanager/documents/advance-he/SDCE\%20Project_Report_Final_Capstone_Report_1594124518.pdf

Poulsen, S., Campbell, C., \& Sankey, M. (2019). The Active Learning Platform a year after implementation: Lessons from the lake of hope. In (Eds.), (pp. 525-530). Retrieved from: http://2019conference.ascilite.org/assets/proceedings/ASCILITE-2019-Proceedings-Final.pdf Personalised Learning. Diverse Goals. One Heart. ASCILITE 2019, Singapore.

Puri, I. K. (2020). 5 ways university education is being reimagined in response to COVID-19. Retrieved 25 October 2020 from https://theconversation.com/5-ways-university-education-is-being-reimagined-inresponse-to-covid-19-144052

Redmond, P., Abawi, L.-A., Brown, A., Henderson, R., \& Heffernan, A. (2018). An online engagement framework for higher education. Online Learning, 22(1), 183-204. https://doi.org/10.24059/olj.v22i1.1175

Smith, C. V., \& Cardaciotto, L. (2011). Is active learning like broccoli? Student perceptions of active learning in large lecture classes. Journal of the Scholarship of Teaching and Learning, 11(1), 53-61.

Veletsianos, G., \& Kimmons, R. (2020). What (some) students are saying about the switch to remote teaching and learning. Educause Review. https://er.educause.edu/blogs/2020/4/what-some-students-are-saying-aboutthe-switch-to-remote-teaching-and-learning

Weimer, M. (2016, June 22). What does student engagement look like? The Teaching Professor. https://www.facultyfocus.com/articles/teaching-and-learning/student-engagement-look-like/?ut

Campbell, C. \& Poulsen, S. (2020). Rapid response to supporting learning and teaching: A whole of university approach. In S. Gregory, S. Warburton, \& M. Parkes (Eds.), ASCILITE's First Virtual Conference. Proceedings ASCILITE 2020 in Armidale (pp. 26-35). https://doi.org/10.14742/ascilite2020.0130

Note: All published papers are refereed, having undergone a double-blind peer-review process. 
The author(s) assign a Creative Commons by attribution licence enabling others to distribute, remix, tweak, and build upon their work, even commercially, as long as credit is given to the author(s) for the original creation.

(C) Campbell, C. \& Poulsen, S. 2020 